\title{
Left ventricular diastolic dysfunction of the cardiac surgery patient; a point of view for the cardiac surgeon and cardio-anesthesiologist Efstratios E Apostolakis ${ }^{1}$, Nikolaos G Baikoussis*1,2, Haralabos Parissis ${ }^{3}$, Stavros N Siminelakis ${ }^{2}$ and Georgios S Papadopoulos ${ }^{4}$
}

Address: ${ }^{1}$ Cardiothoracic Surgery Department, University of Patras, School of Medicine, Patras, Greece, ${ }^{2}$ Cardiac Surgery Department, University of Ioannina, School of Medicine, Ioannina, Greece, ${ }^{3}$ Basildon \& Thurrock University Hospital NHS FT, Basildon, Essex, UK and ${ }^{4}$ Department of Clinical Anesthesiology and Intensive Postoperative Care Unit, University of Ioannina, School of Medicine, Ioannina, Greece

Email: Efstratios E Apostolakis - stratisapostolakis@yahoo.gr; Nikolaos G Baikoussis* - ngbaik@yahoo.com;

Haralabos Parissis - hparissis@yahoo.co.uk; Stavros N Siminelakis -ngbaik@yahoo.com; Georgios S Papadopoulos -ngbaik@yahoo.com

* Corresponding author

Published: 24 November 2009

Journal of Cardiothoracic Surgery 2009, 4:67 doi:10.1186/1749-8090-4-67
Received: 10 July 2009

Accepted: 24 November 2009

This article is available from: http://www.cardiothoracicsurgery.org/content/4/I/67

(C) 2009 Apostolakis et al; licensee BioMed Central Ltd.

This is an Open Access article distributed under the terms of the Creative Commons Attribution License (http://creativecommons.org/licenses/by/2.0), which permits unrestricted use, distribution, and reproduction in any medium, provided the original work is properly cited.

\begin{abstract}
Background: Left ventricular diastolic dysfunction (DD) is defined as the inability of the ventricle to fill to a normal end-diastolic volume, both during exercise as well as at rest, while left atrial pressure does not exceed $12 \mathrm{~mm} \mathrm{Hg}$. We examined the concept of left ventricular diastolic dysfunction in a cardiac surgery setting.
\end{abstract}

Materials and methods: Literature review was carried out in order to identify the overall experience of an important and highly underestimated issue: the unexpected adverse outcome due to ventricular stiffness, following cardiac surgery.

Results: Although diverse group of patients for cardiac surgery could potentially affected from diastolic dysfunction, there are only few studies looking in to the impact of DD on the postoperative outcome; Trans-thoracic echo-cardiography (TTE) is the main stay for the diagnosis of DD. Intraoperative trans-oesophageal (TOE) adds to the management. Subgroups of DD can be defined with prognostic significance.

Conclusion: DD with elevated left ventricular end-diastolic pressure can predispose to increased perioperative mortality and morbidity. Furthermore, DD is often associated with systolic dysfunction, left ventricular hypertrophy or indeed pulmonary hypertension. When the diagnosis of DD is made, peri-operative attention to this group of patients becomes mandatory.

\section{Introduction}

Left ventricular diastolic dysfunction (DD) is defined as the inability of the ventricle to fill to a normal end-diastolic volume, both during exercise as well as at rest, while left atrial pressure does not exceed $12 \mathrm{~mm} \mathrm{Hg}$ [1-3]. It has been shown that several patients with DD are suffering from paroxysmal dyspnoea and "unexplained" pulmo- nary oedema with a normal ejection fraction $[4,5])$. Among patients operated for coronary artery disease or aortic stenosis, the incidence of left ventricular DD ranges widely between $44 \%$, and $75 \%$ [6-10]. The significance and the severity of ventricular diastolic dysfunction among these patients are not well elucidated. On the other hand, estimation of the degree of DD peri-opera- 
tively, is difficult in up to $20 \%$ of cardiac-surgery patients for several reasons $[10,11]$ including rhythm abnormality, preload and afterload alterations, coexistence of valvular disease, age related changes, and inability to obtain proper Doppler images [12-15]. The diastolic heart failure annual mortality varies between 9-28\% (four-fold that of disease-free subjects [16], while it has also been linked to increased incidence of postoperative complications (mortality or morbidity) after cardiac surgery $[13,17,18]$. Revascularization of ischemic myocardium seems to be beneficial for DD (if not immediately), some weeks after revascularization [19]. Potential direct postoperative improvement in diastolic function may be offset by the detrimental effect of global ischemia during cardioplegic arrest in combination with myocardial interstitial oedema $[11,20]$. There are only a few studies concerning surgical outcomes of patients suffering from diastolic dysfunction. Moreover, intra-operative diagnosis and strategies to manage patients with left ventricular diastolic dysfunction are not well clarified. In that sense, diastolic dysfunction could be considered perioperatively as a "Trojan horse".

\section{Source of Research}

Pertinent medical literature in the English language was identified through a Medline computerized literature search and a manual search of selected articles using the key words "left ventricular diastolic dysfunction", "left ventricular diastolic impairment", "transmitral flow Doppler", "pulmonary venous flow patterns". The search terms were combined using the Boolean operator term "or" to find all abstracts pertaining to the chosen search terms. These individual terms were then combined using the Boolean operator term "and" to find articles that contained information of all search terms. The reference lists of articles found through these searches were also reviewed for relevant articles. Links provided on the web sites of published articles were searched for relevant articles.

\section{Pathophysiology}

$\mathrm{DD}$ is present when an elevated filling pressure is necessary to achieve normal ventricular filling. So, DD is related to abnormal left ventricular relaxation and filling during diastolic phase of cardiac cycle [21-24]. During this phase there are four timely and sequential events: a) isovolemic relaxation, b) rapid (early) LV filling, c) slow LV filling (diastasis) and d) atrial contraction $[2,23]$. In figure 1 is shown schematically the pathophysiology of DD. According to echocardiographic depiction, filling of normally relaxed LV is completed in two phases: the first phase is due to the passive filling of the LV, is massive and depicted early in diastole by a high $\mathrm{E}$ wave. The second phase is due to the left atrial contraction, takes place during late diastolic phase, and leads to late LV filling depicted by the wave A of transmitral inflow Doppler [22,25]. The rate of decrease of $\mathrm{E}$ wave in early diastole depends on the rate of increase in LV pressure and is represented by the so-called deceleration time (DT). This time is influenced by a number of factors such as, a) left atrial-left ventricular pressure gradient at the time of mitral valve opening, b) left atrial chamber compliance, c) left ventricular chamber compliance, d) grade of left ventricle relaxation, e) viscoelastic forces of the myocardial wall, $f$ ) pericardial restraint and finally g) left-right ventricular interaction. Left ventricular relaxation-similar to contraction- is an energy-dependent process, because it requires the reuptake of calcium into the sarcoplasmic reticulum [26]. When patients with left ventricular DI are subjected to stress-as occurs during surgery or during faster heart ratesdue to shorter diastolic filling time available, the ventricle is not allowed to relax and fill properly; thus, causing increased left ventricular end-diastolic pressure and pulmonary congestion $[1,2,16]$. Furthermore, relaxation of the left ventricle is determined by visco-elasticity and restoring forces (recoil). It is believed that impaired diastolic filling of the left ventricle is the first manifestation of active ischemia and results in an upward shift of left ventricular diastolic pressure-volume relationship $[2,26]$. Decreased activity of sarcoplasmic reticulum calcium ATPase pump (SERCA) can slow down calcium removal out of the cytosolic net [27]. In contrast, increased levels or activity of phospholamban-the natural SERCA-inhibitory protein-can also impair relaxation. Hypothyroidism decreases SERCA and increases phospholamban, leading to impaired relaxation, while the opposite effect occurs in hyperthyroidism [27]. In a similar way, increasing the action of SERCA by administration of captopril, and $\beta$-agonists (or decreasing the action of phospholamban), results in improvement of diastolic relaxation [28].

\section{Pathophysiology and diagnosis of DD}

Another aspect of DD is the relationship between systolic and diastolic left ventricular dysfunction $[2,29,30]$ Increased left ventricular end systolic volume for example, affects the rate of left ventricular relaxation, and as a result, patients with reduced $\mathrm{LV}$ ejection fractions are expected to have a prolonged relaxation time [2]. Loading conditions, such as inotropic stimulation and neurohumoral factors generally affect both systolic and diastolic function in a parallel way [2]. As it has been shown, elevated left ventricular end-diastolic pressure may or may not be associated with systolic dysfunction of left ventricle, suggesting left ventricular DD even in the absence of reduced left ventricular ejection fraction [29]. Indeed, patients with symptoms of heart failure and normal ejection fraction have significant abnormalities in active relaxation and passive stiffness, which cause increased left ventricular end-diastolic pressure [30]. Literature review: "The theory" of DD is presented in table 1. 


\section{Stimuli}

Ischemia, LV strain, Age, Arrhythmia, Systolic LV dysfunction, CPB (Cardio-

Pulmonary Bypass) or $\downarrow$ activity of SERCA

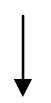

Impaired diastolic filling
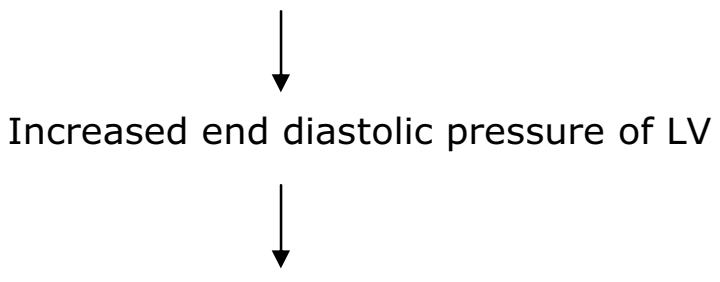

Upwards and to the left shift of LV pressure/volume relationship

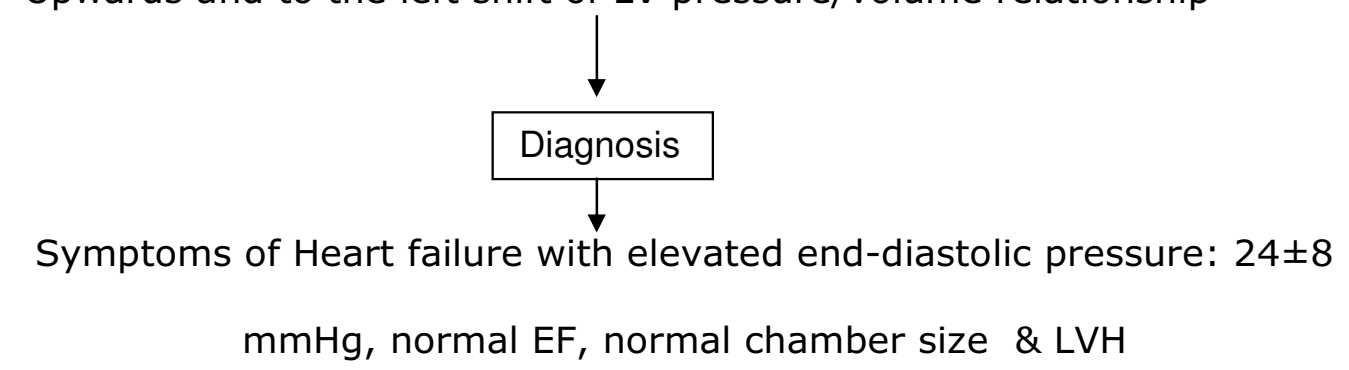

non-invasive (Doppler, MR-myocardial tagging,radionuclide ventriculography) and invasive (micromanometry, angiography).

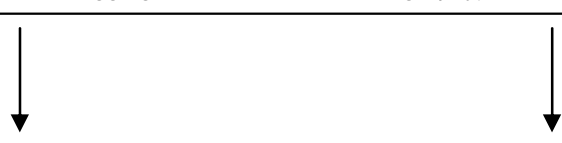

Prolonged relaxation pattern $\mathrm{E} / \mathrm{A}=1$

time constant of LV relaxation is longer $>50-55 \mathrm{msec}$

Pseudonormal pattern

LV passive -stiffness constant is high $>0.025$

Restrictive pattern

$\mathrm{E} / \mathrm{A}=2$ and $\mathrm{DT}=150 \mathrm{~ms}$

E-wave deceleration $350 \pm 140 \mathrm{~ms}$

Figure I

Pathophysiology of DD and its consequences. 
Table I: Articles "investigating the background" of the entity Diastolic Heart Failure (DHF).

\begin{tabular}{|c|c|c|c|}
\hline Author & Year & Journal & Conclusions \\
\hline Kessler KM et al [35] & 1989 & Hosp Pract & Introduction of the term DHF \\
\hline Paulus W] [67] & 1999 & Cardiovasc Res. & Development of specific diagnostic criteria for DHF \\
\hline Bruch C et al [68] & 2000 & Eur Heart J & Tei-index: relation to LVEDP, sensitive indicator of overall cardiac dysfunction \\
\hline Mandinov L et al [69] & 2000 & Cardiovasc Res & Doppler--Echo definitions \\
\hline Vasan and Levy [70] & 2000 & Circulation & Development of criteria for definite, probable and possible DHF \\
\hline Crossman W [16] & 2000 & Circulation & Thoughtful Editorial \\
\hline Zile MR et al [7I] & 2001 & Circulation & $\begin{array}{l}\text { Tested the hypothesis that measurements of the LV relaxation and passive stiffness were } \\
\text { not necessary to make the diagnosis of DHF }\end{array}$ \\
\hline Poulsen SH et al [72] & 2001 & Dan Med Bull & DHF following acute $\mathrm{MI}$ \\
\hline Catuzzo B et al [73] & 2003 & J Card Fail & Regarding patients with CHF: BNP plasma levels is related to diastolic restrictive pattern \\
\hline Hogg $\mathrm{K}$ et al $[2 \mathrm{I}]$ & 2004 & J Am Coll Cardiol & $\begin{array}{l}\text { Epidemiology of the syndrome of heart failure with preserved LV systolic function: clinical } \\
\text { characteristics }\end{array}$ \\
\hline Zile MR et al [30] & 2004 & N Engl J Med & $\begin{array}{l}\text { Invasive assessment of DHF. Identification of significant abnormalities in active relaxation } \\
\text { and passive stiffness }\end{array}$ \\
\hline Yturralde RF et al [74] & 2005 & Prog Cardiovasc Dis & Review and current recommendations \\
\hline Zile MR et al [75]) & 2005 & Prog Cardiovasc Dis & Overview of systolic and DHF \\
\hline Shammas RL et al [76] & 2007 & Int J Cardiol & DHF: "what we don t know" \\
\hline Scardovi AB et al [77] & 2007 & Eur J Echocardiogr & BNP and advanced DHF \\
\hline
\end{tabular}

Literature review: "The Theory" of DD

\section{Diagnosis of DD in a Cardiothoracic setting}

Assessment and diagnosis of DD can be performed with non-invasive (2D and Doppler-echocardiography, colour Doppler M-mode, Doppler tissue imaging, MR-myocardial tagging, radionuclide ventriculography) and invasive techniques (micromanometry, angiography, conductance method). Typical findings of primary DD in chest radiograph include absence of cardiomegaly and presence of pulmonary congestion. Electrocardiogram/ECHO reveals the presence of excessive concentric hypertrophy in combination with normal ejection fraction [5]. Measurement of peak early filling wave (E wave: is caused by difference in atrium-ventricle pressure) and atrial filling wave (A wave: is caused by atrial contraction) ratio by Doppler echocardiography, as well as deceleration time (DT: is caused by left ventricular compliance), are useful screening tools for abnormal left ventricular relaxation [29]. In presence of abnormal relaxation, atrial contraction occurs in an incompletely empty atrium and blood is propelled into the left ventricle in increased velocity, accounting for the heightened A wave and consequent decreased E/A ratio. Blood flow in the pulmonary veins is biphasic, with peaks of forward flow occurring in both systole and diastole and inverse diastolic flow occurring during atrial contraction. There is an inverse relationship between left atrial pressure and pulmonary venous systolic flow. That is the reason why determination of systolic pulmonary venous flow velocity is a rapid method to estimate LV filling pressures after CABG [30].

\section{Pathological filling is determined from transmitral flow pattern}

1) Prolonged relaxation pattern: characterized by prolonged isovolumetric relaxation time and deceleration time, low $\mathrm{E}$ and high A wave velocities with an E/A wave ratio typically 1 . It is related to the remodelling process including hypertrophy or scarring of an infarct zone leading to a non-uniform LV relaxation. 
2) Pseudonormal pattern: an intermediate stage between prolonged relaxation and restrictive filling as a consequence of disease progression. There is an association with atrial dilatation and prominent pulmonary venous wave reversal.

3) Restrictive pattern: associated with shortened isovolumetric relaxation time, increased peak $\mathrm{E}$ wave velocity with very short deceleration time and small A wave, leading to an E/A wave ratio of 2. This pattern might be due to increasing LV volume and also to increased myocardial stiffness. DD is severe when the transmitral filling pattern E/A ratio is 2 and the deceleration time is $150 \mathrm{~ms}$.

For patients undergoing cardiac surgery, Doppler assessment of transmitral flow has been used to estimate postoperative left ventricular filling pressure, relaxation, and stiffness [31]. The most important problem in evaluating transmitral flow patterns is their great variation, depending on many factors such as: heart rate [32,33], preload [34], afterload [34], positive-pressure mechanical ventilation [21], systolic ventricular function [35,36], use of inotropic or generally vasoactive agents due to their effect on the afterload [34,37], and hemodilution (higher velocities due to reduced blood viscosity) [34]. To surmount this, a new method for diagnosis of LV diastolic dysfunction, the so called flow propagation velocity (Vp) is applied. It bears the advantage of being insensitive to heart rate and preload changes [10]. According to Vp measurement, left ventricular filling patterns does not change significantly after cardiopulmonary bypass. Furthermore, newer techniques such as tissue Doppler imaging (TDI) which measures high intensity, low velocity echo of the myocardium has been developed. By using TDI, local myocardial relaxation can be calculated by obtaining the velocity of early diastolic wall motion (Em) and it's timing [38]. In other words, TDI allows assessment of diastolic function because of its unique ability to assess regional abnormalities in relaxation, in addition to their global effect on ventricular relaxation and filling dynamics. An E/Em ratio > 10 remains the best discriminatory value when it is used as a single parameter for the prediction of elevated filling pressures or simply diastolic dysfunction [39]. However, definite diagnosis of diastolic dysfunction is established by cardiac catheterization and direct measurement of pressure at the end of systole and volume loops [40]. This invasive assessment of diastolic function allows the study of isovolumic relaxation (time constant of $\mathrm{LV}$ relaxation is longer $>50-55 \mathrm{msec}$ ) and evaluation of the passive elastic properties of the myocardium (LV passive-stiffness constant is high).

\section{Intraoperative diagnosis}

Intraoperative diagnosis of diastolic dysfunction is difficult, $[41,42]$ because: a) most variables measuring diastolic function depend on loading conditions, heart rate and age $[32-34,43]$, b) no single individual measurement can fully characterize left ventricular diastolic dysfunction, and c) ECHO estimation may give different results whether it is performed with the patient awake and breathing spontaneously, or anesthetized and receiving positive pressure ventilation [35]. Diastolic dysfunction of left ventricle can be intraoperatively diagnosed, estimated and graded by using Trans Oesophageal Echo (TOE). Moreover, valuable information may be obtained with the additional use of a Swan-Ganz catheter [33,34,39]. According to Ranucci [44], first degree of diastolic dysfunction of the left ventricle is depicted as impaired relaxation, is usually observed just after discontinuation of cardiopulmonary bypass, and is often reversible (temporary). Second degree mimicking pseudonormalization, is a more severe condition, which sometimes is an intermediate step towards, third degree of dysfunction which is characterized by a restrictive pattern. An increased ratio ( $>2$ ) between $\mathrm{E}$ and A waves of transmitral flow, and a blunted systolic waveform of the pulmonary vein flow is present due to left atrial pressure [34,36,39]. It has been demonstrated that mitral and pulmonary vein flow indexes correlate with pulmonary capillary wedge pressure (PCWP) $[44,45]$. Therefore, additional measurement of PCWP by using a Swan-Ganz catheter may be in this phase useful in estimating the time course of diastolic dysfunction and the effect of therapeutic manipulations [44]. Fluid responsiveness is better defined by TOE derived variables (left ventricular end-diastolic area, peak blood velocity variation), but some information can be derived by the Swan-Ganz catheter as well (PCWP and peak pulmonary pressure variation) $[45,46]$. In table 2 we present the high risk groups for developing DD, while in table 3, we report articles looking into: the impact of diastolic dysfunction (DD) on patient's outcome following Cardiac Surgery.

\section{Progression of DD following Cardiac surgery}

Following coronary artery bypass grafting, DD is temporarily deteriorated (expressed as a decrease in E-max and an increase in A-max of transmitral flow) [47]. This deterioration of DD seems to persist, at least for the first three postoperative hours after coronary artery bypass grafting $[48,49]$. In a similar way, Yamamoto et al by using classical ECHO after coronary artery bypass grafting, showed that DD was characterized by a decrease in $\mathrm{E}$ wave velocity, prolongation of the E wave DT, and a decrease of E/A ratio [43]. Potential implicated mechanisms are those of free oxygen radicals, altered intracellular calcium homeostasis, or both [50,51]. Temporary improvement has been shown, especially if calcium channels blocking factors like 
Table 2: High risk groups for developing DD

\begin{tabular}{ll}
\hline Systolic dysfunction & $\begin{array}{l}\text { Only } 50 \% \text { to } 60 \% \text { of patients with clinical findings of congestive heart failure have an abnormal systolic function, which is } \\
\text { indicated by reduced ejection fraction. The remaining } 40 \%-50 \% \text { of pts, have congestive heart failure with normal systolic } \\
\text { function and represent the patients with diastolic dysfunction [22,23]. For clarification, Sanderson proposed the term "heart } \\
\text { failure with normal ejection fraction" (HFNEF) for left ventricular diastolic dysfunction, and heart failure with reduced } \\
\text { ejection fraction (HFREF) for systolic dysfunction of left ventricle [78]. According to this classification, the main difference } \\
\text { between HFNEF and HFREF is the degree of ventricular remodeling accompanied by increased ventricular volume in HFREF } \\
\text { [78]. In other words, distinction between systolic and diastolic dysfunction is very important because the latter has a lower } \\
\text { mortality (5\%-8\% annually), and requires different medical management (no inotropes) [22,23]. }\end{array}$ \\
\hline LVH & $\begin{array}{l}\text { In patients with AS, preoperative DD is attributable to hypertension, myocardial hypertrophy- fibrosis, and/or to ischemia } \\
\text { [64]. }\end{array}$ \\
\hline CAD & $\begin{array}{l}\text { Patients with CAD are prone for the development of postoperative myocardial diastolic dysfunction [39]. Left ventricular } \\
\text { filling abnormalities have been detected in as many as } 90 \% \text { of patients [39]. Possible related factors that were considered } \\
\text { were ischemia, hypertrophy, and hypertension [79]. }\end{array}$ \\
\hline DM & $\begin{array}{l}\text { All insulin--dependent diabetes mellitus patients with left diastolic dysfunction had evidence of definite autonomic neuropathy } \\
\text { [80]. Moreover, diabetic patients with autonomic neuropathy form a subgroup of particularly high mortality and } \\
\text { cardiovascular event risk [8I,82]. }\end{array}$ \\
\hline Age & $\begin{array}{l}\text { Aging is correlated to DD through an increase upon wall thickness (secondary to enlargement of cardiac myocytes), and } \\
\text { changes in the vasculature, the diameter, and vascular stiffness of the aorta and large arteries [83]. Up to 60\% of geriatric } \\
\text { patients with normal EF, following non-cardiac surgery, had been postoperatively diagnosed with diastolic dysfunction [35]. }\end{array}$
\end{tabular}

High risk groups for DD

diltiazem were perioperatively administered or added in the cardioplegic solution $[43,50,52,53]$. For patients who underwent off-pump coronary artery bypass grafting (OPCAB), comparative studies on the postoperative changes in left ventricular diastolic function, have shown that, while left ventricular diastolic dysfunction impairment was observed in both groups (conventional CABG and $\mathrm{OPCAB}$ ), it was more significantly impaired in the CABG group [54]. Other studies showed that right ventricular diastolic dysfunction was in a similar way significantly impaired after CABG and OPCAB $[43,55,56]$, and this deterioration persisted in up to one year postoperatively [15]. In contrast to this, Shi et al who evaluated short- and long-term evolution of biventricular diastolic performance postoperatively in 49 pts who underwent coronary artery bypass grafting showed that postoperative deterioration of diastolic dysfunction had an absolute return to preoperative status at six months postoperatively [9].

Table 3: Articles looking into: The impact of diastolic dysfunction (DD) on patient's outcome following Cardiac Surgery.

\begin{tabular}{llll}
\hline Authors & Year & Journal & Conclusions \\
\hline Casthely et al [84] & 1997 & J Thorac Cardiovasc Surg & The effects of myocardial protection on diastolic function after cardiac operations \\
\hline Bernard F et al [13] 2001 & Anesth Analg & $\begin{array}{l}\text { The significance of diastolic dysfunction perioperatively; Diastolic dysfunction is } \\
\text { associated with difficult weaning from CPB. }\end{array}$ \\
\hline Vaskelyte J [18] & 200I & Eur J Echocardiogr & $\begin{array}{l}\text { The interesting concept to subdivide patients with severe LV dysfunction into different } \\
\text { groups according to diastolic filling pattern abnormality. One of the few articles } \\
\text { investigating the relationship between diastolic dysfunction and post-operative mortality. } \\
\text { Drawbacks: All patients had low EF < 35\%. }\end{array}$
\end{tabular}

Liu J et al [17] $2003 \quad$ Am J Cardiol
The prognostic value of transmitral flow patterns on patients following CABG; Probably one of the most important papers on the subject. The study claims that pseudonormal and restrictive TMF patterns, correlates with short term adverse outcome

Malouf PJ [85] 2006 J Am Soc Echocardiogr

Doppler tissue imaging of mitral annular velocity: Lateral segmental velocity has advantages over the septal segmental velocity 


\section{Management of DD}

According to a multivariate analysis by Bernard et al [13], left ventricular diastolic dysfunction was a better predictor of hemodynamic instability after cardiac surgery compared to systolic dysfunction. Treatment of the underlying disease is currently the most important therapeutic approach. In patients with tachycardia, use of b-blockers or calcium antagonists, is beneficial so as to prolong diastolic (filling) time [24,57]. Treatment of atrial fibrillation by cardioversion or amiodarone infusion is indicated in patients with diastolic dysfunction [22,24,57]. In addition, digitalis may decelerate ventricular rate in cases of permanent atrial fibrillation, and contribute to better ventricular filling [58]. Denault et al [59] developed a diagnostic algorithm which they then applied to a group of 74 cardiac surgical patients, to determine whether moderate to severe left ventricular diastolic dysfunction (LVDD) and right ventricular diastolic dysfunction (RVDD) can predict difficult discontinuation of cardiopulmonary bypass. Patients with moderate to severe LVDD tended to have higher PCWP compared to those with normal to mild LVDD. The presence of moderate to severe RVDD was also associated with lower mean pulmonary artery pressure and lower cardiac index compared to patients with normal to mild RVDD. Difficult separation from cardiopulmonary bypass was present in $65.5 \%$ and $72 \%$ of patients with moderate/severe LVDD and RVDD respectively, in contrast to $40.9 \%$ and $48 \%$ of patients with nor$\mathrm{mal} /$ mild LVDD/RVDD. They concluded that moderate and severe degree of LVDD and RVDD can be identified with very good reproducibility, and both degrees of diastolic dysfunction are associated to difficult discontinuation from cardiopulmonary bypass [59]. During this effort, transesophageal echo is a needful tool to estimate the degree of diastolic dysfunction, as well as preload and afterload. Appropriate increase of volume load is a milestone of timing in order to discontinue cardiopulmonary bypass. Phosphodiesterase inhibitors seem to be beneficial for diastolic dysfunction improvement, and should be used in perioperatively [60]. In a similar way, Levosimendan may used in perioperative management of diastolic dysfunction [61]. It increases cardiac output and decreases pulmonary capillary wedge pressures. This mode of enhanced contractile force generation is achieved without an increase in myocardial oxygen consumption, intracellular calcium concentrations, or an adverse effect on diastolic function [61]. For the next postoperative days milestone of treatment remain diuretics, in doses which prevent dyspnea and liver congestion on one side, but not reduce the cardiac output on the other [57]. ACE inhibitors in combination with spironolactone are beneficial because they prevent excessive activation of rennin-angiotensin-aldosterone system, and improve ventricular relaxation although not yet confirmed $[62,63]$. In contrast to systolic dysfunction, use of calcium antagonists alone or in combination with ACE, contributes effectively in hypertension control and has a beneficial influence on hypertrophic myocardium [23,24,58]. In patients with diastolic dysfunction due to hypertrophic cardiomyopathy (either idiopathic or due to acquired aortic valve stenosis), the main problem is to load the left ventricle with adequate volume (preload) because it is common to notice an echo-finding of low preload (i.e. very low left ventricular end-diastolic area), while the measured PCWP is found high [55]. Such patients need increased volumes, but each fluid administration should be carefully guided by constant measurement of PCWP, in order to avoid an abrupt increase in pulmonary venous pressure and consequent acute pulmonary oedema [55]. Postoperatively, use of intra-aortic balloon pump in patients with left ventricular diastolic dysfunction seems to result in a favourable influence on left ventricular function [34]. Possible explanations for this effect lie on the positive effects of balloon on coronary flow against ischemia, the favourable effect on systolic function of left ventricle, and the increase of left ventricular long axis [34]. For those cases whereby "restricted pattern" is diagnosed, inotropic agents should be considered. Maslow et al showed that the use of inotropes in 44 patients, who underwent AVR for stenosis, was associated with significantly larger increase in right ventricular ejection fraction and cardiac output after $\mathrm{CPB}$ [64]. Changes in cardiac output and index were more strongly correlated with changes in RVEF than LVEF. Lastly, infusion of a new B-natriuretic peptide (BNP) nesiritide was associated with increased $\mathrm{CO}$ in patients with diastolic dysfunction and low CO syndromes undergoing cardiac surgery, when other measures failed. This agent seems to offer an additional option to inotropes and fluid challenges perioperatively [65]. Castellá et al in an experimental study conducted in pigs in 2006, demonstrated that temporary LAD ischemia alters the normal sequential pattern of contraction responsible for ejection and suction through reduction of the systolic contractile force, and prolongation of the endocardial contraction into early diastole to disrupt the normal endocardial-epicardial sequence responsible for ventricular suction [66]. The systolic and diastolic effects of myocardial stunning were studied to evaluate the role of the endocardial and epicardial segments and to determine if preconditioning by $\mathrm{Na}+\mathrm{H}+$ exchange (NHE) inhibition effect post-stunning dysfunction. In this study conducted in YorkshireDuroc pigs, NHE inhibition before ischemia limits postischemic systolic and diastolic dysfunction by re-establishing the expected shortening sequences within the ventricular myocardial band model [66].

\section{Conclusion}

There are only few studies looking in to the impact of DD on the outcome following cardiac surgery. Without doubt DD with elevated left ventricular end-diastolic pressure 
can predispose to increased perioperative mortality and morbidity. Furthermore, DD is often associated with systolic dysfunction, left ventricular hypertrophy or indeed pulmonary hypertension. The mainstay of management of DD starts with the prompt recognition and diagnosis of this entity and relies on the aggressive management of the underlie aetiology of this insidious disease.

\section{Competing interests}

The authors declare that they have no competing interests.

\section{Authors' contributions}

All authors: 1. have made substantial contributions to conception and design, or acquisition of data, or analysis and interpretation of data; 2 . have been involved in drafting the manuscript or revisiting it critically for important intellectual content; 3 . have given final approval of the version to be published.

\section{References}

I. Kitzman DW, Little WC, Brubaker PH, Anderson RT, Hundley WG, Marburger CT, Brosnihan B, Morgan TM, Stewart KP.: Pathophysiological characterization of isolated diastolic heart failure in comparison to systolic heart failure. JAMA 2002, 288:2 I44-50.

2. Rodeheffer R, Miller W, Burnett J: Pathophysiology of circulatory failure. In Mayo Clinic Practice of Clinical Cardiology 3rd edition. Edited by: Giuliani E, Gersh B, Megoon M, Hayes D, Schaff H. Mosby; 1996:556-58.

3. Vasan R, Benjamin E, Levy D: Prevalence, clinical features and prognosis of diastolic heart failure: an epidemiologic perspective. J Am Coll Cardiol 1995, 26: I565-74.

4. Kramer K, Kirkman P, Kitzman D, Little WC.: Flash pulmonary edema: association with hypertension and reoccurrence despite coronary revascularization. Am Heart J 2000, | 40:45 I-5.

5. Givetz $M$, Colucci W, Braunwald $E$ : Clinical aspects of heart failure;Pulmonary edema, High-output failure. In Braunwald's Heart Disease 7th edition. Edited by: Zipes D, Libby P, Bonnow R, Braunwald E. Elsevier Saunders; 2005:54|-43.

6. Lappas DG, Skubas NJ, Lappas GD, Ruocco E, Tambassis E, Pasque M.: Prevalence of left ventricular diastolic filling abnormalities in adult cardiac surgical patients: an intraoperative echocardiographic study. Sem Thorac Cardiovasc Surg 1999, I I: I 25-33.

7. Djaiani GN, McCreath BJ, Ti LK, Mackensen BG, Podgoreanu M, Phillips-Bute B, Mathew JP.: Mitral flow propagation velocity identifies patients with abnormal diastolic function during coronary artery bypass graft surgery. Anesth Analg 2002, 95:524-30.

8. Mathison M, Edgerton JR, Horswell JL, Akin JJ, Mack MJ.: Analysis of hemodynamic changes during beating heart surgical procedures. Ann Thorac Surg 2000, 70:|355-6I.

9. Shi Y, Denault AY, Couture P, Butnaru A, Carrier M, Tardif JC: Biventricular diastolic filling patterns after coronary artery bypass graft surgery. J Thorac Cardiovasc Surg 2006, I 3 I: I080-86.

10. Malouf JF, Enriquez-Sarano M, Pellikka PA, Oh JK, Bailey KR, Chandrasekaran K, Mullany CJ, Tajik AJ.: Severe pulmonary hypertension in patients with severe aortic stenosis: clinical profile and prognostic implications. JACC 2002, 40:789-95.

II. Royse CF, Royse AG, Blake DW, Grigg LE.: Instantaneous end diastolic stiffness (IEDS): a simple, load independent measurement of left ventricular diastolic function in patients undergoing cardiacsurgery. Ann Thorac Cardiovasc Surg 2000, 6:203-10.

12. Kim Y-J, Sohn D-W: Mitral annulus velocity in the estimation of left ventricular filling pressure; prospective study in $\mathbf{2 0 0}$ patients. J Am Soc Echocardiogr 2000, I 3:980-5.
13. Bernard F, Denault A, Babin D, Goyer C, Couture P, Couturier A, Buithieu J.: Diastolic dysfunction is predictive of difficult weaning from cardiopulmonarybypass. Anesth Analg 2001, 92:29I-98.

14. Lappas DG, Skubas NJ, Lappas GD, Ruocco E, Tambassis E, Pasque M: Prevalence of left ventricular diastolic filling abnormalities in adult cardiac surgical patients: an intraoperative echocardiographicstudy. Sem Thorac Cardiovasc Surg 1999, I I: I25-33.

15. Alam M, Hedman A, Nordlander R, Samad B.: Right ventricular function before and after an uncomplicated coronary artery bypass graft as assessed by pulsed wave Doppler tissue imaging of the tricuspid annulus. Am Heart J 2003, I 46:520-26.

16. Grossman W: Defining diastolic dysfunction. Circulation 2000, I0I:2020-I.

17. Liu J, Tanaka N, Murata K, Ueda K, Wada Y, Oyama R, Matsuzaki M.: Prognostic value of pseudonormal and restrictive filling patterns on left ventricular remodeling and cardiac events after coronary artery bypass grafting. Am J Cardiol 2003, 9 I:550-54.

18. Vaskelyte J, Stoskute N, Kinduris S, Ereminiene E.: Coronary artery bypass grafting in patients with severe left ventricular dysfunction: predictive significance of left ventricular diastolic filling pattern. Eur J Echocardiogr 200I, 2:62-67.

19. Natsuaki M, Itoh T, Ohteki H, Minato N, Ishii K, Suda H.: Evaluation of left ventricular early diastolic function after coronary artery bypass grafting relating to myocardial damage. Jpn Circ J 1991, 55:117-24.

20. Houltz E, Hellström A, Ricksten SE, Wikh R, Caidahl K: Early effects of Coronary artery bypass surgery and cold cardioplegic ischemia on left ventricular diastolic function: evaluation by computerassisted transesophageal echocardiography. J Cardiothorac Vasc Anesth 1996, 10:728-33.

21. Hogg K, Swedberg K, McMurray J: Heart failure with preserved left ventricular systolic function: Epidemiology, clinical characteristics, and prognosis. JACC 2004, 43:317-327

22. Zile M, Brutsaerd D: New concepts in diastolic dysfunction and diastolic heart failure: Part I: Diagnosis, prognosis, and measurement of diastolic function. Circulation 2002, I 05: I 387-93.

23. Zile M, Brutsaerd D: New concepts in diastolic dysfunction and diastolic heart failure: Part II: Causal mechanisms and treatment. Circulation 2002, 105:1503-8.

24. Angeja B, Grossman W: Evaluation and management of diastolic heart failure. Circulation 2003, I I ; I 07(5):659-63.

25. Naqvi T: Diastolic function assessment incorporating new techniques in Doppler echocardiography. Rev Cardiovasc Med 2003, 4:8I-99.

26. Braunwald E, Zipes DP, Libby P: Normal and abnormal cardiac function: mechanisms of cardiac contraction and relaxation. In Heart Diseases 6th edition. Edited by: Zohrab R, GeryL, Reilly S etal. Philadelphia: WB Saunders Company; 2001:451-4.

27. Cain BS, Meldrum DR, Joo KS, Wang JF, Meng X, Cleveland JC Jr, Banerjee $A$, Harken AH.: Human SERCA2a levels correlate inversely with age in senescent human myocardium. JAAC 1998, 32:458-67.

28. Lubien E, DeMaria A, Krishnaswamy P, Clopton P, Koon J, Kazanegra R, Gardetto N, Wanner E, Maisel AS.: Utility of B-natriuretic peptide in detecting diastolic dysfunction: comparison with Doppler velocity recordings. Circulation 2002, I05:595-60I.

29. European Study Group on Diastolic Heart Failure. How to diagnose diastolic heart failure. Eur Heart J 1998, 19:990-1003.

30. Zile M, Baicu C, Gaasch W: Diastolic heart failure-Abnormalities in active relaxation and passive stiffness of the left ventricle. N Engl ] Med 2004, 350:1953-59.

31. McKenney PA, Apstein CS, Mendes LA, Connelly GP, Aldea GS, Shemin RJ, Davidoff R.: Increased left ventricular diastolic chambers stiffness immediately after coronary artery bypass surgery. JAAC 1994, 24: I I89-94.

32. Nishimura R, Tajik A: Evaluation of diastolic filling of left ventricle in health and disease: Doppler echocardiography is the clinician's Rosetta stone. JAAC 1997, 30:8-18.

33. Yamamoto K, Masuyama T, Tanouchi J, Doi Y, Kondo H, Hori M, Kitabatake A, Kamada T.: Effects of heart rate on left ventricular filling dynamics: Assessment from simultaneous recordings of pulsed Doppler transmitral flow velocity pattern and hemodynamic variables. Cardiovasc Res 1993, 27:935-4I.

34. Maaten JM van der, de Vries AJ, Henning RH, Epema AH, Berg MP van den, Lip H: Effects of preoperative treatment with diltiazem 
on diastolic ventricular function after coronary artery bypass graft surgery. J CardiothoracVasc Anesth 200 I, I5:710-16.

35. Kessler KM: Diastolic heart failure. Diagnosis andmanagement. Hosp Pract (Off Ed) 1989, 24(7):|37-4I.

36. Tresch $D, M c G o u g h$ M: Heart failure with normal systolic function: a common disorder in old people. J Am Geriatr Soc 1995, 43: $1035-42$.

37. Ridker PM, Rifai N, Rose L, Buring JE, Cook NR: Comparison of Creactive protein and low-density lipoprotein cholesterol levels in the prediction of first cardiovascular events. $N$ Engl Med 2002, 347: 1557-65.

38. De Boeck BW, Cramer MJ, Oh JK, Aa RP van der, Jaarsma W: Spectral pulsed tissue Doppler imaging in diastole: a tool to increase our insight in and assessment of diastolic relaxation of the leftventricle. Am Heart J 2003, I46:4 I I-9.

39. Nagueh SF, Lakkis NM, Middleton KJ, Spencer WH, Zoghbi WA, Quiñones MA.: Doppler estimation of left ventricular filling pressures in patients with hypertrophic cardiomyopathy. Circulation 1999, 99:254-61.

40. Bonow $R$, Udelson J: Left ventricular diastolic dysfunction as a cause of congestive heart failure: mechanisms and mangament. Annlntern Med 1992, I 1 7:50I-10.

4I. del Monte F, Williams E, Lebeche D, Schmidt U, Rosenzweig A Gwathmey JK, Lewandowski ED, Hajjar RJ.: Improvement in survival and cardiac metabolism after gene transfer of sarcoplasmic reticulum $\mathrm{Ca}(2+)$-ATPase in a rat model of heart failure. Circulation 200I, 104:1424-9.

42. De Hert SG, Linden PJ Vander, ten Broecke PW, De Mulder PA, Rodrigus IE, Adriaensen HF: Assessment of length-dependent regulation of myocardial function in coronary surgery patients using transmitral flow velocity patterns. Anesthesiology 2000, 93:374-81.

43. Yamamoto K, Nishimura RA, Chaliki HP, Appleton CP, Holmes DR $J r$, Redfield MM: Determination of left ventricular filling pressure by Doppler echocardiography in patients with coronary artery disease: Critical role of left ventricular systolic function. JACC 1997, 30:1819-26.

44. Ranucci $\mathrm{M}$ : Which cardiac surgical patients can benefit from placement of a pulmonary artery catheter? Crit Care 2006, I0(Suppl 3):S6.

45. Lattik R, Couture P, Denault AY, Carrier M, Harel F, Taillefer J, Tardif JC.: Mitral doppler indices are superior to two-dimensional echocardiographic and hemodynamic variables in predicting responsiveness of cardiac output to a rapid intravenous infusion of colloid. Anesth Analg 2002, 94:1092-1099.

46. DiCorte CJ, Latham P, Greilich PE, Cooley MV, Grayburn PA, Jessen ME.: Esophageal doppler monitor determinations of cardiac output and preload during cardiac operations. Ann Thorac Surg 2000, 69:1782-1786.

47. McKenney PA, Apstein CS, Mendes LA, Connelly GP, Aldea GS, Shemin RJ, Davidoff R.: Increased left ventricular diastolic chambers stiffness immediately after coronary artery bypass surgery. JAAC 1994, 24: I 189-94.

48. Ekery DL, Davidoff R, Orlandi QG, Apstein CS, Hesselvik JF, Shemin RJ, Shapira OM.: Imaging and diagnostic testing: diastolic dysfunction after coronary artery bypass grafting: a frequent finding of clinical significance not influenced by intravenous calcium. Am Heart J 2003, I45:896-902.

49. Skarvan K, Filipovic M, Wang J, Brett W, Seeberger M.: Use of myocardial tissue Doppler imaging for intraoperative monitoring of left ventricular function. Br J Anesth 2003, $91: 473-80$.

50. Gardin JM, Arnold AM, Bild DE, Smith VE, Lima JA, Klopfenstein HS, Kitzman DW: Left ventricular diastolic filling in the elderly: the cardiovascular health study. Am J Cardiol |998, 82:345-5|.

51. Hess M: Free radicals, calcium homeostasis, heat shock proteins, and myocardial stunning. Ann Thorac Surg 1995, 60:760-66.

52. Malhotra R, Mishra M, Kler TS, Kohli VM, Mehta Y, Trehan N.: Cardioprotective effects of diltiazem infusion in the perioperativeperiod. Eur J Cardiothorac Surg 1997, I 2:420-27.

53. Seitelberger R, Hannes W, Gleichauf M, Keilich M, Christoph M, Fasol R.: Effects of diltiazem on perioperative ischemia, arrhythmias, and myocardial function in patients undergoing elective coronary bypass grafting. J Thorac Cardiovasc Surg 1994 |07:8||-2|.
54. Ng KK, Popovic ZB, Troughton RW, Navia J, Thomas JD, Garcia MJ.: Comparison of left ventricular diastolic function after onpump versus off-pump coronary artery bypass grafting. $\mathrm{Am} J$ Cardiol 2005, 95:647-50.

55. Michaux I, Filipovic M, Skarvan K, Schneiter S, Schumann R, Zerkowski HR, Bernet F, Seeberger MD: Effects of on-pump versus off-pump coronary artery bypass graft surgery on right ventricularfunction. J Thorac Cardiovasc Surg 2006, I 3 I: | 28I-88.

56. Kwak YL, Oh YJ, Jung SM, Yoo KJ, Lee JH, Hong YW: Change in right ventricular function during off-pump coronary artery bypass graft surgery. Eur J Cardiothorac Surg 2004, 25:572-77.

57. Bristow M, Lowes $B$ : Management of heart failure. In Braunwald's Heart Disease 7th edition. Edited by: Zipes D, Libby P, Bonnow R, Braunwald E. Elsevier Saunders; 2005:610.

58. Lee T: Management of heart failure. In Braunwald's Heart Disease 7th edition. Edited by: Zipes D, Libby P, Bonnow R, Braunwald E. Elsevier Saunders; 2005:623-24.

59. Denault AY, Couture P, Buithieu J, Haddad F, Carrier M, Babin D, Levesque $S$, Tardif JC.: Left and right ventricular diastolic dysfunction as a predictors of difficult separation from cardiopulmonary bypass. Can J Anesth 2006, 53:1020-29.

60. Mitrovic V, Strasser R, Berwing K, Thormann J, Schlepper M.: Acute effects of enoximone after intracoronary administration on hemodynamics, myocardial perfusion, and regional wall motion. Z Kardiol 1996, 85:856-67.

61. $\mathrm{Ng} \mathrm{T}$, Akhter M: Levosimendan: dual mechanisms for acute heart failure....and beyond? Minerva Cardioangiol 2005, 53:565-84.

62. Yusuf S, Pfeffer MA, Swedberg K, Granger CB, Held P, McMurray J], Michelson EL, Olofsson B, Ostergren J, CHARM Investigators and Committees: Effects of candesartan in patients with chronic heart failure and preserved left ventricular ejection fraction. Lancet 1994, 362:767-7I.

63. Okura $Y$, Nakashima $Y$, Tojo H, Tashiro E, Saku K.: Valsartan, an angiotensin II typa-I receptor blocker, and left ventricular diastolic function. A case report. Angiology 2005, 56:67-73.

64. Maslow AD, Regan MM, Schwartz C, Bert A, Singh A.: Inotropes improve right heart function in patients undergoing aortic valve replacement for aortic stenosis. Anesth Analg 2004, 98:891-902.

65. Gordon GR, Schumann R, Rastegar H, Khabbaz K, England MR. Nesiritide for treatment of perioperative low cardiac output syndromes in cardiac surgical patients: an initial experience. | Anesth 2006, 20:307-II.

66. Castellá M, Buckberg GD, Saleh S: Diastolic dysfunction in stunned myocardium: a state of abnormal excitation-contraction coupling that is limited by $\mathrm{Na}+-\mathrm{H}+$ exchange inhibition. Eur J CardiothoracSurg 2006, 29(SuppI I):SI07-14. Epub 2006 Mar 27.

67. Paulus WJ, Shah AM: NO and cardiac diastolic function. Cardiovasc Res 1999, 43(3):595-606.

68. Bruch C, Schmermund A, Marin D, Katz M, Bartel T, Schaar J, Erbe $\mathrm{R}$ : Tei-index in patients with mild-to-moderate congestiveheart failure. Eur Heart / 2000, 21(22): I888-95.

69. Mandinov L, Eberli FR, Seiler C, Hess OM: Diastolic heartfailure. Cardiovasc Res 2000, 45(4):813-25.

70. Vasan RS, Levy D: Defining diastolic heart failure: a call for standardized diagnostic criteria. Circulation 2000, 102:2118-2121.

7I. Zile MR, Gaasch WH, Carroll JD, Feldman MD, Aurigemma GP, Schaer GL, Ghali JK, Liebson PR: Heart failure with a normal ejection fraction: is measurement of diastolic function necessary to make the diagnosis of diastolic heart failure? Circulation 200I, I 04(7): 779-82

72. Poulsen SH: Clinical aspects of left ventricular diastolic function assessed by Doppler echocardiography following acute myocardial infarction. Dan Med Bull 200I, 48(4): I99-2I0.

73. Catuzzo B, Ciancamerla F, Bobbio M, Longo M, Trevi GP: In patients with severe systolic dysfunction, only brain natriuretic peptide is related to diastolic restrictive pattern. J Card Fail 2003 , 9(4):303-10.

74. Yturralde RF, Gaasch WH: Diagnostic criteria for diastolic heart failure. Prog Cardiovasc Dis 2005, 47(5):3।4-9.

75. Zile MR, Baicu CF, Bonnema DD: Diastolic heart failure. Definitions and terminology. Prog Cardiovasc Dis 2005, 47(5):307-13.

76. Shammas RL, Khan NU, Nekkanti R, Movahed A: Diastolic heart failure and left ventricular diastolic dysfunction: what we 
know, and what we don't know! Int J Cardiol 2007, I I 5(3):284-92. Epub 2006 Aug 14.

77. Scardovi AB, Coletta C, Aspromonte N, Perna S, Greggi M, D'Errigo $P$, Sestili $A$, Ceci V: Brain natriuretic peptide plasma level is a reliable indicator of advanced diastolic dysfunction in patients with chronic heart failure. Eur J Echocardiogr 2007, 8(I):30-6.

78. Sanderson J: Diastolic heart failure or heart failure with a normal ejection fraction. Minerva Cardioangiol 2006, 54:7I5-24.

79. Aronson S, Boisvert D, Lapp W: Isolated systolic hypertension is associated with adverse outcomes from coronary artery bypass grafting surgery. Anesth Analg 2002, 94: 1079-84.

80. Rajan S, Gokhale S: Cardiovascular function in patients with insulin-dependent diabetes mellitus: a study using noninvasivemethods. Ann N Y Acad Sci 2002, 958:425-30.

81. Zola B, Kahn J, Juni J: Abnormal cardiac function in diabetic patients with autonomic neuropathy in the absence of ischemic heart disease. J Clin Endocrinol Metab 1986, 63:208-14.

82. Ewing D, Campbell I, Clarke B: Heart rate changes in diabetes mellitus. Lancet 1981, I:183-6.

83. Yamada H, Goh PP, Sun JP, Odabashian J, Garcia MJ, Thomas JD, Klein AL: Prevalence of left ventricular diastolic dysfunction by Doppler echocardiography: clinical application of the Canadian Consensus Guidelines. J Am Soc Echocardiogr 2002, I 5:1238-44.

84. Casthely PA, Shah C, Mekhjian H, Swistel D, Yoganathan T, Komer C, Miguelino RA, Rosales R: Left ventricular diastolic function after coronary artery bypass grafting: a correlative study with three different myocardial protection techniques. J Thorac CardiovascSurg 1997, I I 4(2):254-60.

85. Malouf PJ, Madani M, Gurudevan S, Waltman TJ, Raisinghani AB, DeMaria AN, Blanchard DG: Assessment of diastolic function with Doppler tissue imaging after cardiac surgery: effect of the "postoperative septum" in on-pump and off-pump procedures. J Am Soc Echocardiogr 2006, I 9(4):464-7.

Publish with Biomed Central and every scientist can read your work free of charge

"BioMed Central will be the most significant development for disseminating the results of biomedical research in our lifetime. "

Sir Paul Nurse, Cancer Research UK

Your research papers will be:

- available free of charge to the entire biomedical community

- peer reviewed and published immediately upon acceptance

- cited in PubMed and archived on PubMed Central

- yours - you keep the copyright

Submit your manuscript here:

http://www.biomedcentral.com/info/publishing_adv.asp
BiolMedcentral 